ISSN 1392-3196 / e-ISSN 2335-8947

Zemdirbyste-Agriculture, vol. 101, No. 1 (2014), p. 101-108

DOI 10.13080/z-a.2014.101.014

\title{
Control of ascochyta blight (Ascochyta complex) in pea under Lithuanian conditions
}

\author{
Rūta ČESNULEVIČIENE $\dot{1}^{1}$, Irena GAURILČIKIENE ${ }^{2}$, Jūratè RAMANAUSKIENE ${ }^{2}$ \\ ${ }^{1}$ Perloja Experimental Station, Lithuanian Research Centre for Agriculture and Forestry \\ Sodo 12, Perloja, Varèna distr., Lithuania \\ E-mail: perloja@perloja.lt \\ ${ }^{2}$ Institute of Agriculture, Lithuanian Research Centre for Agriculture and Forestry \\ Instituto 1, Akademija, Kèdainiai distr., Lithuania \\ E-mail: irenag@1zi.lt
}

\begin{abstract}
During the period 2008-2010, in different soil and climate conditions: 1) in Middle Lowland of Lithuania in Dotnuva, 2) in Southeast Lithuania in Perloja, experiments were conducted to investigate the peculiarities of ascochyta blight control using seed treatment and fungicide application. Commercial seed from the same lot of the pea variety 'Pinochio' was sown in Dotnuva and Perloja. Two seed treatment agents - Raxil extra (a.i. tebuconazole + thiram $15+500 \mathrm{~g} \mathrm{l}^{-1}$ ) in a dose rate $2.01 \mathrm{t}^{-1}$ and Kinto (a.i. triticonazole + prochloraz $20+60 \mathrm{~g} \mathrm{l}^{-1}$ ) $1.51 \mathrm{t} \mathrm{t}^{-1}$ and two fungicides applied at flowering - Signum (a.i. boscalid + piraclostrobin $267+67 \mathrm{~g} \mathrm{~kg}^{-1}$ ) $1.0 \mathrm{~kg} \mathrm{ha}^{-1}$ and Bravo (a.i. chlorothalonil $500 \mathrm{~g} \mathrm{l}^{-1}$ ) $3.01 \mathrm{ha}^{-1}$ were used.

Ascochyta blight severity was significantly reduced by pea seed treatment and/or by fungicide application at flowering stage. The values of the area under disease progress curve (AUDPC) of ascochyta blight in the fungicideapplied plots in most cases were significantly lower in Dotnuva compared with those in Perloja. The frequency of detection of the pathogens of Ascochyta complex on pea pods and grain depended on the level of ascochyta blight incidence on plants. With rising infection level, the frequency of detection of pathogens both on pods and grain increased. In Perloja, the fungi of Ascochyta complex on grain were detected in all experimental years, while in Dotnuva only in 2010. The grains of pea crops spray-applied with the fungicides Signum and Bravo in two years out of three were less infected with the pathogens of Ascochyta complex, compared with those from the unsprayed plots. Pea grain yield increments resulting from the use of seed treatment and fungicide application were inconsistent in both experimental sites. It was noted that the values of productivity indicators, 1000 grain weight (TGW) and pod number per plant were higher for the Raxil extra seed-treated plots spray-applied with the fungicides Signum and Bravo; in separate years these values significantly differed from the untreated/unsprayed. In Perloja, in 2008, a significant negative correlation was established between the AUDPC values of ascochyta blight and pod and grain number per plant $(P \leq 0.01)$, and grain weight per plant and TGW $(P \leq 0.05)$. Low correlation coefficients were obtained in Dotnuva because of lower ascochyta blight infection there.
\end{abstract}

Key words: ascochyta blight, Ascochyta complex, AUDPC, fungicides, Pisum sativum, yield.

\section{Introduction}

Ascochyta blight is widespread in all pea growing regions. Its causal agents are Ascochyta pisi Lib., Mycosphaerella pinodes (Berk, Bloxam) Vestergr., Phoma pinodella (Jones) Morgan-Jones Burch., which are often referred to in literature as Ascochyta complex (Onfroy et al., 1999). Ascochyta blight accelerates the maturity of affected pea crops, the plants lose water in stems and leaves, the disease also accelerates seed desiccation, reduces seed weight, disturbs nutrient metabolism and reduces photosynthetic potential of plants (Garry et al., 1998). If plants are infected with ascochyta blight before flowering, seed set is declined, while if infection occurs at the beginning of seed formation stage, this results in a reduction in seed weight. The more severely the plant is affected, the greater the reduction in seed weight per plant is. In severely affected pea crops, a reduction in seed number per plant can total $18 \%$ and $25 \%$, and seed yield reduction $-13.5 \%$ and $16.7 \%$ (Tivoli et al., 1996). Yield losses to ascochyta blight ( $M$. pinodes) depend on the time infection spreads in the crop. Having artificially infected pea at the stage of 8-10 internodes, in the middle of flowering and pod formation stage, grain yield losses in 1994 amounted to 31, 24 and 19\%, and in 1995 to 33, 43 and $30 \%$, respectively (Xue et al., 1997).

A. pisi seed-borne infection is a major source of initial infection in the crop; therefore seed treatment is an important preventive measure against further spread of the disease (Bretag et al., 2008). Conversely, for the 
epidemiology of $M$. pinodes the seed infected with the disease propagules is not a significant source of infection for ascochyta blight incidence on the aerial plant part of pea; however, it causes severe seedling rots and reduces seed germination (Moussart et al., 1998). P. pinodella at seedling stage causes stem blackening and a slight reduction in seedling weight (Persson et al., 1997). A complex of measures: elimination or evasion of disease infection source, optimal sowing time, and use of seed free from disease infection, seed treatment and fungicide application on crops, choice of varieties with increased resistance represent the best pea cultivation practice (Davidson, Kimber, 2007).

Pea varieties characterised by a high resistance to ascochyta blight have not been developed yet. Research efforts have been predominantly focused on the search for sources of resistance to $M$. pinodes infection. Highly promising sources of resistance have been found in Canada (Xue, Warketin, 2001), New Zealand (Kraft et al., 1998), and the United Kingdom (Clulow et al., 1992). The yield losses of the ascochyta blight-tolerant pea varieties 'Baccara' and 'Yellowhead' developed in Canada were $10 \%$ and $17 \%$, respectively, while those of ascochyta blight-susceptible lines ranged from $30 \%$ to 49\% (Xue, Warkentin, 2001).

Fungicides for pea ascochyta blight control were started to be applied on a wider scale in the last decade of last century. Having used chlorothalonil in the crops of 10 pea varieties, a significant reduction in ascochyta blight was achieved as well as an increase in TGW in all three experimental years; however, the variety $\times$ fungicide interaction was insignificant in all years. The yield increase resulting from fungicide application amounted to on average $6.4 \%$ and TGW increase ranged between $0.9-5.1 \%$. Moreover, the pea seed sprayed with chlorothalonil was $19.2 \%$ less infected with $M$. pinodes propagules (Xue et al., 2003). In Brazil, the recommended control of pea ascochyta blight in a pea crop is a single spray application with fungicide containing active ingredients piraclostrobin and epoxiconazole (Tomm et al., 2004). Ascochyta blight control in vetchling crops using from one to five spray applications with chlorothalonil, mancoceb and piraclostrobin, depending on the year was sufficient when sprayed once-twice. The third application still gave some extra effect but the subsequent ones did not give any reduction in the disease severity. Having investigated the susceptibility of $A$. rabiei spores to the fungicides used, it was found that $70 \%$ of isolates were resistant to piraclostrobin or chlorothalonil (Chang et al., 2007).

The susceptibility of Lithuania-grown pea varieties to ascochyta blight is not known; moreover, there are no scientifically validated recommendations concerning measures and practices designed for the reduction of damage done by ascochyta blight in pea crops. The aim of the current research was to estimate the feasibility of control of ascochyta blight using seed treatment and fungicide application and to assess the impact of seed treatment and fungicide application on field pea productivity and yield components.

\section{Materials and methods}

Ascochyta blight control. During the period 2008-2010, in different climate and soil conditions: 1) in Middle Lowland of Lithuania in Dotnuva, 2) in Southeast Lithuania in Perloja, experiments were conducted to investigate the peculiarities of ascochyta blight control, using seed treatment and fungicide application. In Dotnuva, the sum of active temperatures $\left(\Sigma \mathrm{T}>10^{\circ} \mathrm{C}\right)$ is $2100-2200^{\circ} \mathrm{C}$, and annual amount of precipitation is $500-600 \mathrm{~mm}$, and in Perloja $-2100-2300^{\circ} \mathrm{C}$ and 600 $700 \mathrm{~mm}$, respectively (Regionalism of climate, http:// www.meteo.lt/klim_rajonavimas.php). In Dotnuva, Endocalcary-Endohypogleyic Cambisol (CMg-n-w-can), with $\mathrm{pH}_{\mathrm{KCL}} 7.0$ and $2.3-2.4 \%$ humus, and in Perloja Hapli-Albic Luvisol (LVa-ha), with $\mathrm{pH}_{\mathrm{KCL}} 5.5$, and 1.6\% humus prevailed (Buivydaite et al., 2001).

The experimental design involved seed treatment and fungicide application in crops. In all experimental years (2008-2010), the seed of the pea cv. 'Pinochio' was sown. Commercial seed from the same lot was sown in Dotnuva and Perloja. Two seed treatment agents were chosen for the study - Raxil extra (a.i. tebuconazole + thiram $15+500 \mathrm{~g} \mathrm{l}^{-1}$ ) and Kinto (a.i. triticonazole + prochloraz $20+60 \mathrm{~g} \mathrm{l}^{-1}$ ) and two fungicides - Signum (a.i. boscalid + piraclostrobin $267+67 \mathrm{~g} \mathrm{~kg}^{-1}$ ) and Bravo (a.i. chlorothalonil $500 \mathrm{~g} \mathrm{l}^{-1}$ ). The rates of the seed treatment agents and fungicides are provided in Table 1.

Table 1. Experimental design of field trials in Dotnuva and Perloja, 2008-2010

\begin{tabular}{clcc}
\hline $\begin{array}{c}\text { Treat- } \\
\text { ment } \\
\text { No. }\end{array}$ & Seed treatment / fungicide & $\begin{array}{c}\text { Rate of seed } \\
\text { treatment } \\
\mathrm{ml} 100 \mathrm{~kg}^{-1} \\
\text { seed }\end{array}$ & $\begin{array}{c}\text { Rate of } \\
\text { fungicide } \\
1.0 \mathrm{~kg} \mathrm{ha}^{-1}\end{array}$ \\
\hline 1. & Untreated / without fungicides & - & - \\
2. & Untreated / Signum & - & 1.0 \\
3. & Untreated / Bravo & - & 3.0 \\
4. & Kinto / without fungicides & 150 & - \\
5. & Raxil extra / without fungicides & 200 & - \\
6. & Kinto / Signum & 150 & 1.0 \\
7. & Raxil extra / Signum & 200 & 1.0 \\
8. & Kinto / Bravo & 150 & 3.0 \\
9. & Raxil extra / Bravo & 200 & 3.0 \\
\hline
\end{tabular}

Pea seed was treated with a seed treating machine "Amazone" (Germany), with the water slurry of $11100 \mathrm{~kg}^{-1}$. The experimental plots $(3 \times 20 \mathrm{~m})$ were sown with a drilling machine "Fiona" (Denmark) with a row spacing of $12.5 \mathrm{~cm}$, four replications, at a seed rate of 1 million viable seeds ha ${ }^{-1}$. Fungicides were sprayed at pea flowering stage (BBCH 61-65) with a precision, small-plot bicycle sprayer using compressed nitrogen, flat-fan nozzles 4110-12. The assessments of the severity of ascochyta blight were started at the time of disease appearance in the crop and were continued every 14-18 days until maturity. Ascochyta blight severity on 25 plants per plot was estimated in percent according to the disease-affected plant and pod surface. The severity of ascochyta blight per season was expressed by the area 
under disease progress curve (AUDPC) value (Campbell, Madden, 1990). Biological efficacy of the fungicides was calculated according to Abbott (1925). Plant phenological development stage was determined according to $\mathrm{BBCH}$ scale (Weber, Bleiholder, 2001).

Meteorological conditions. In 2008, in Dotnuva the sum of effective temperatures $\left(\sum \geq 5^{\circ} \mathrm{C}\right)$ was significantly higher than that in Perloja nearly throughout the whole growing season; however, the amount of rainfall was markedly higher in Perloja. In 2009, a slightly higher sum of effective temperatures since early spring was recorded in Dotnuva, while in the summer months in Perloja. The year 2009 was distinguished by a droughty spring, especially in the Middle Lithuania zone. Later in the season, both experimental sites received a similar amount of rainfall, except for the downpour in Dotnuva, where $74 \mathrm{~mm}$ of rainfall fell within 4 hours on June 23. In 2010, unlike in the previous year, there was more rainfall and rainy days in spring in Dotnuva; however, the first two ten-day periods of June and July were wetter in Perloja, except for July third ten-day period when Dotnuva received as much as $101 \mathrm{~mm}$ more rainfall than Perloja.

The effect of seed treatment and fungicide application onfield pea productivity and yield components. At pea grain maturity stage, before harvesting, sheaves of $50(5 \times 10)$ pea plants were formed from each plot for the determination of pod number per plant, grain number and weight per plant $(\mathrm{g})$. Grain yield was harvested at complete maturity with a combine harvester "Wintersteiger Delta" (Germany) in Dotnuva and with "Sampo 500" (Finland) in Perloja. The harvested grains were weighed and 2 $\mathrm{kg}$ samples were taken for the establishment of grain moisture content and 1000 grain weight (TGW), and seed infection with the pathogens of Ascochyta complex.
Frequency of detection of pathogens of Ascochyta complex was investigated by cultivating pieces of pods and seeds on an oat agar medium (Roger, Tivoli, 1996). The pathogens of Ascochyta complex were identified according to the morphological traits typical of the colonies (Punithalingam, Holliday, 1972 a; b; Punithalingam, Gibson, 1976). Frequency of detection of Ascochyta complex pathogens and A. pisi relative density in Ascochyta complex were calculated (González et al., 1995).

Statistical data analysis. The experimental data were processed by the analysis of variance method. The significant difference of data was estimated according to Fisher criteria. The method of binary regression and correlation analysis of data was used to estimate the interaction between AUDPC of ascochyta blight and yield and yield components. Statistical analysis was done using the statistical data processing software package SELEKCIJA (software ANOVA, STAT) (Tarakanovas, Raudonius, 2003).

\section{Results and discussion}

Ascochyta blight control in field pea using fungicides. In 2008, at the time of fungicide application there were no symptoms of ascochyta blight in pea crops in both experimental sites. In Perloja, the spread of the disease became more intensive at grain-formation stage, while in Dotnuva at ripening stage. At ripening stage in all the treatments applied with ascochyta blight control measures, such as seed treatment, application of fungicides or their combinations, the disease severity was significantly $(P \leq 0.01)$ lower than in the untreated (Table 2). In Dotnuva, ascochyta blight did not spread on pods, and in Perloja, only single symptoms of the disease were observed in the plots not applied with fungicides (Table 3).

Table 2. Ascochyta blight severity (R\%) at ripening stage on pea plants and biological efficacy (BE\%) of fungicide application and seed treatment in Dotnuva and Perloja in 2008-2010

\begin{tabular}{|c|c|c|c|c|c|c|}
\hline \multirow{2}{*}{ Treatments } & \multicolumn{2}{|c|}{2008} & \multicolumn{2}{|c|}{2009} & \multicolumn{2}{|c|}{2010} \\
\hline & $\mathrm{R} \%$ & $\mathrm{BE} \%$ & $\mathrm{R} \%$ & $\mathrm{BE} \%$ & $\mathrm{R} \%$ & $\mathrm{BE} \%$ \\
\hline & \multicolumn{6}{|c|}{ Dotnuva } \\
\hline 1. Untreated / unsprayed & 15.8 & - & 3.3 & - & 39.3 & - \\
\hline 2. Untreated / Signum & $0.8^{* *}$ & 94.9 & 3.5 & 0 & $21.4 * *$ & 45.5 \\
\hline 3. Untreated / Bravo & $0.8 * *$ & 94.9 & 3.1 & 6.1 & 34.4 & 12.5 \\
\hline 4. Kinto / unsprayed & $7.8 * *$ & 50.6 & 3.8 & 0 & 34.4 & 12.5 \\
\hline 5. Raxil extra / unsprayed & $13.1 *$ & 17.1 & $1.6^{*}$ & 51.5 & 37.9 & 3.6 \\
\hline 6. Kinto / Signum & $0.6^{* *}$ & 96.2 & 2.7 & 18.2 & $23.8 * *$ & 39.4 \\
\hline 7. Raxil extra / Signum & $0.6^{* *}$ & 96.2 & 2.3 & 30.3 & $20.9 * *$ & 46.8 \\
\hline 8. Kinto / Bravo & $0.4 * *$ & 97.5 & 2.2 & 33.3 & 33.9 & 13.7 \\
\hline \multirow[t]{2}{*}{ 9. Raxil extra / Bravo } & $1.7 * *$ & 89.2 & $1.9^{*}$ & 42.4 & 33.5 & 14.8 \\
\hline & \multicolumn{6}{|c|}{ Perloja } \\
\hline 1. Untreated / unsprayed & 5.7 & - & 20.0 & - & 40.0 & - \\
\hline 2. Untreated / Signum & $1.4 * *$ & 75.4 & $13.1 * *$ & 34.5 & $24.5 * *$ & 38.8 \\
\hline 3. Untreated / Bravo & $1.8 * *$ & 68.4 & $14.5 * *$ & 27.5 & $30.0^{*}$ & 25.0 \\
\hline 4. Kinto / unsprayed & $2.3 * *$ & 59.6 & $16.5^{*}$ & 17.5 & $31.4 *$ & 21.5 \\
\hline 5. Raxil extra / unsprayed & $2.2 * *$ & 61.4 & $17.0^{*}$ & 15.0 & $29.4 * *$ & 26.5 \\
\hline 6. Kinto / Signum & $1.5^{* *}$ & 73.7 & $13.0 * *$ & 35.0 & 33.0 & 17.5 \\
\hline 7. Raxil extra / Signum & $1.3 * *$ & 77.2 & $12.8 * *$ & 36.0 & $26.6 * *$ & 33.5 \\
\hline 8. Kinto / Bravo & $1.3 * *$ & 77.2 & $15.0 * *$ & 25.0 & $31.2 *$ & 22.0 \\
\hline 9. Raxil extra / Bravo & $1.1 * *$ & 80.7 & $14.7 * *$ & 26.5 & $24.0 * *$ & 40.0 \\
\hline
\end{tabular}

*,** $-F$-test significant at $P>0.05$ and $P>0.01$, respectively 
Table 3. Ascochyta blight severity (R\%) at ripening stage on pea pods and biological efficacy (BE\%) of fungicide application and seed treatment in Dotnuva and Perloja in 2008-2010

\begin{tabular}{|c|c|c|c|c|c|c|}
\hline \multirow{2}{*}{ Treatments } & \multicolumn{2}{|c|}{2008} & \multicolumn{2}{|c|}{2009} & \multicolumn{2}{|c|}{2010} \\
\hline & $\mathrm{R} \%$ & $\mathrm{BE} \%$ & $\mathrm{R} \%$ & $\mathrm{BE} \%$ & $\mathrm{R} \%$ & $\mathrm{BE} \%$ \\
\hline & \multicolumn{6}{|c|}{ Dotnuva } \\
\hline 1. Untreated / unsprayed & 0 & - & 1.0 & - & 2.6 & - \\
\hline 2. Untreated / Signum & 0 & - & 0 & 100 & 1.7 & 34.6 \\
\hline 3. Untreated / Bravo & 0 & - & 0 & 100 & 2.2 & 15.4 \\
\hline 4. Kinto / unsprayed & 0 & - & 1.35 & 0 & 1.9 & 26.9 \\
\hline 5. Raxil extra / unsprayed & 0 & - & 0.8 & 20.0 & 1.8 & 30.8 \\
\hline 6. Kinto / Signum & 0 & - & 0 & 100 & 1.6 & 38.5 \\
\hline 7. Raxil extra / Signum & 0 & - & 0 & 100 & 2.1 & 19.2 \\
\hline 8. Kinto / Bravo & 0 & - & 0 & 100 & 2.0 & 23.1 \\
\hline \multirow[t]{2}{*}{ 9. Raxil extra / Bravo } & 0 & - & 0 & 100 & 1.8 & 30.8 \\
\hline & \multicolumn{6}{|c|}{ Perloja } \\
\hline 1. Untreated / unsprayed & 0.5 & - & 1.5 & - & 3.5 & - \\
\hline 2. Untreated / Signum & 0 & 100 & 0 & 100 & $1.9 * *$ & 45.7 \\
\hline 3. Untreated / Bravo & 0 & 100 & 0 & 100 & $2.1 * *$ & 40.0 \\
\hline 4. Kinto / unsprayed & 0.5 & 0 & 0.9 & 40.0 & $2.1 * *$ & 40.0 \\
\hline 5. Raxil extra / unsprayed & 0.3 & 40.0 & 1.1 & 26.7 & $1.6 * *$ & 54.3 \\
\hline 6. Kinto / Signum & 0 & 100 & 0 & 100 & $1.9 * *$ & 45.7 \\
\hline 7. Raxil extra / Signum & 0 & 100 & 0 & 100 & $1.6^{* *}$ & 54.3 \\
\hline 8. Kinto / Bravo & 0 & 100 & 0 & 100 & $2.4 * *$ & 31.4 \\
\hline 9. Raxil extra / Bravo & 0 & 100 & 0 & 100 & $1.7 * *$ & 51.4 \\
\hline
\end{tabular}

** $-F$-test significant at $P>0.01$

In 2009, in Perloja, ascochyta blight occurred at flowering stage. In the plots sown with treated seed and sprayed with fungicides at grain ripening stage, the disease severity was significantly lower than in the untreated/ unsprayed. In Dotnuva, where ascochyta blight occurred at the end of grain-formation stage, a significant disease severity reduction was noted only for the treatments (in two out of three) sown with Raxil extra-treated seed. In the plots, not applied with fungicides at flowering stage, ascochyta blight in Dotnuva spread on the majority of pods, and in Perloja on all pods; however, the disease incidence was low. The pods of fungicide-sprayed plants were not affected.

In the exceptionally rainy year of 2010 , both in Perloja and Dotnuva the spread of ascochyta blight was particularly intensive. In Perloja, it started to manifest itself at the bud formation stage; at maturity ascochyta blight severity was significantly lower both on plants and pods in all the plots applied with the disease control measures. In Dotnuva, the trend towards disease severity reduction both on plants and pods was observed in all treatments; however, only the plots applied with Signum were significantly less affected. In the plots, sown with treated seed and spray-applied with fungicides, the AUDPC values of ascochyta blight in most cases were significantly lower than in the control (Table 4). Comparison of the AUDPC values between the plots sprayed with Signum and Bravo fungicides did not reveal any distinct difference; however, in Dotnuva, under the conditions of severe infection in 2010, the AUDPC values of ascochyta blight of Signum-applied plots were markedly lower than those of Bravo-applied plots.

Summarised results of ascochyta blight control using fungicides enable us to maintain that when treated seed was sown and fungicides were spray-applied at the flowering stage, the severity of ascochyta blight in a pea crop was significantly reduced. Seed treatment was also an effective measure to reduce ascochyta blight infection in pea crops.

Bretag et al. (2008) research findings suggest that seed treatment is an important measure preventing further spread of the disease when $A$. pisi seed infection is a major infection source in the crop. However, Moussart et al. (1998) indicated that M. pinodes-infected seed is not a significant source of infection for the disease to spread on aerial plant part. The authors have ascertained that seed infection with $M$. pinodes causes severe seedling rots, reduces seed germination, but the lesions remain below soil surface; however, when irrigated or rain fed, infection can spread onto foliage. Research done by Xue et al. (1996) showed no significant relationship between the level of seed infection with $M$. pinodes and ascochyta blight incidence in the crop. The study done by Gorfu and Sangchote (2003) confirmed that pea seed treatment inhibited ascochyta blight infection only at early growth stage; however, seed treatment gave a significant increase in pea productivity. To achieve an effective ascochyta blight control, the crops were sprayed with fungicides 1-5 times (Bretag et al., 1995; Xue et al., 2003). Research done in India evidenced that the best ascochyta blight control was given by seed treatment with thiram, and during the growing season by a three-time sprayapplication of chlorothalonil (Panicker, Ramraj, 2010). However, such intensive use of fungicides may result in the development of fungicide resistance in ascochyta blight causal agents (Chang et al., 2007).

The effect of fungicide application on the frequency of detection of the pathogens of Ascochyta complex on pea pods and grain. The frequency of detection of Ascochyta complex on the pods and grain of plants spray-applied with fungicides at flowering stage was highly dependent on the year and ascochyta blight severity in the experimental sites. In Dotnuva, where ascochyta blight severity was low in 2009 , the grains 
Table 4. The effect of seed treatment with Kinto and Raxil extra and fungicide application with Signum and Bravo on the area under disease progress curve (AUDPC) values of ascochyta blight in pea crops in Dotnuva and Perloja in 2008-2010

\begin{tabular}{lccc|ccc}
\hline & \multicolumn{9}{c}{ AUDPC values } \\
\cline { 2 - 7 } \multicolumn{1}{c}{ Treatment } & \multicolumn{3}{c}{ Dotnuva } & \multicolumn{3}{c}{ Perloja } \\
\cline { 2 - 7 } & 2008 & 2009 & 2010 & 2008 & 2009 & 2010 \\
\hline 1. Untreated / unsprayed & 103 & 31 & 514 & 91 & 265 & 618 \\
2. Untreated / Signum & $6^{* *}$ & 27 & $264^{* *}$ & $35^{* *}$ & $204^{* *}$ & $400^{* *}$ \\
3. Untreated / Bravo & $5^{* *}$ & 31 & $421^{*}$ & $31^{* *}$ & 226 & $478^{*}$ \\
4. Kinto / unsprayed & $49^{*}$ & $16^{*}$ & 434 & $49^{* *}$ & 246 & 502 \\
5. Raxil extra / unsprayed & $8^{*}$ & 26 & $421^{*}$ & $47^{* *}$ & 256 & 513 \\
6. Kinto / Signum & $5^{* *}$ & 22 & $226^{* *}$ & $31^{* *}$ & $204^{* *}$ & 534 \\
7. Raxil extra / Signum & $4^{* *}$ & 22 & $185^{* *}$ & $21^{* *}$ & $197^{* *}$ & $426^{*}$ \\
8. Kinto / Bravo & $3^{* *}$ & 21 & $383^{* *}$ & $20^{* *}$ & 226 & 527 \\
9. Raxil extra / Bravo & $11^{* *}$ & $19^{*}$ & $311^{* *}$ & $17^{* *}$ & $221^{*}$ & $382^{* *}$ \\
\hline
\end{tabular}

*, ** $-F$-test significant at $P>0.05$ and $P>0.01$, respectively

were not infected with Ascochyta complex, although the frequency of detection of the pathogens was rather high on pods (Tables 3 and 5). With higher severity of ascochyta blight, which was the case both in Dotnuva and Perloja in 2008 and 2010, an increase in the frequency of detection of Ascochyta complex on pods and grain was noted. At severe incidence of ascochyta blight, the grains of the fungicide spray-applied plants were less infected with the pathogens of Ascochyta complex in two years out of three, compared with the grain from the unsprayed plots.
The frequency of detection of pathogen species of Ascochyta complex differed between experimental years: in 2008, in both experimental sites the prevalent species was A. pisi, in 2009 A. pisi accounted for nearly half of the isolated pathogens of Ascochyta complex; in 2010, in Dotnuva, A. pisi accounted for the larger half of the population, whereas in Perloja the prevalent species were $M$. pinodes and $P$. pinodella. Our research evidenced that in separate years the infection pressure from the pathogens of Ascochyta complex can be high on pea grains.

Table 5. The effect of fungicides on the frequency of detection (FD\%) of pathogens of Ascochyta complex and relative density (RD\%) of A. pisi in A. complex on pea pods and grain in Dotnuva and Perloja in 2008-2010

\begin{tabular}{|c|c|c|c|c|c|c|c|}
\hline \multirow{2}{*}{ Year } & \multirow{2}{*}{ Indicators } & Unsprayed & Signum & Bravo & Unsprayed & Signum & Bravo \\
\hline & & & Dotnuva & & & Perloja & \\
\hline & & \multicolumn{6}{|c|}{ Pods } \\
\hline \multirow{2}{*}{2008} & A. complex FD\% & 7.0 & 10.0 & 3.0 & - & - & - \\
\hline & A. pisi $\mathrm{RD} \%$ & 100 & 100 & 30.0 & - & - & - \\
\hline \multirow{2}{*}{2009} & A. complex FD $\%$ & 51.1 & 82.0 & 91.1 & 100 & 100 & 100 \\
\hline & A. pisi RD \% & 13.1 & 22.0 & 12.2 & 40.0 & 14.0 & 15.6 \\
\hline \multirow{3}{*}{2010} & A. complex FD $\%$ & 86.0 & 72.0 & 58.0 & 93.3 & 80.0 & 80.0 \\
\hline & A. pisi RD \% & 68.6 & 66.7 & 65.5 & 14.3 & 25.0 & 0 \\
\hline & & \multicolumn{6}{|c|}{ Grain } \\
\hline \multirow{2}{*}{2008} & A. complex FD\% & 0 & 0 & 0 & 78.0 & 27.0 & 38.0 \\
\hline & A. pisi RD \% & 0 & 0 & 0 & 100 & 77.8 & 18.4 \\
\hline \multirow{2}{*}{2009} & A. complex $\mathrm{FD} \%$ & 1.0 & 0 & 0 & 76.0 & 60.0 & 100 \\
\hline & A. pisi RD \% & 100 & 0 & 0 & 40.0 & 28.0 & 52.0 \\
\hline \multirow{2}{*}{2010} & A. complex FD $\%$ & 9.0 & 2.0 & 10.0 & 31.0 & 8.0 & 0 \\
\hline & A. pisi RD \% & 88.9 & 50.0 & 100 & 0 & 100 & 0 \\
\hline
\end{tabular}

TheresultsofstudiesconductedbyMarcinkowska (2008) in our neighbouring country Poland in 2004-2006 indicated that the detection frequency of Ascochyta complex pathogens on pea seeds from various regions of Poland was highly dependent on the year and local conditions. A. pisi was isolated every year but pathogen detection frequency was as low as $0.02-1.54 \%$. $M$. pinodes and $P$. pinodella were detected only in two out of three years; however, their detection frequency was even lower than that of $A$. pisi. Seed infection with $M$. pinodes was found to be predominant in France (Fougereux et al., 2006) and Canada (Xue et al., 1997).
The effect of seed treatment and fungicide application on field pea grain yield and yield components. Until flowering stage, the roots and foot of the pea plants in the seed-treated plots were less affected by rots (Gaurilčikienè et al., 2012), while fungicides provided a good suppression of ascochyta blight severity on plants, therefore the yield increases resulting from the application of these measures were inconsistent (Table 6). This is likely to have been caused by a combination of the narrow experimental plots and showery weather: at the edges of the narrow plots pea plants lodged on the paths and in rainy conditions with heavy downpours in 2009 in Perloja and in 
2010 in both experimental sites, the pea plants were badly lodged, which made their harvesting complicated. TGW of peas in Perloja in 2008 and 2009 was significantly higher in two out of three treatments with the fungicide Signum, and in 2010 in all Signum-treatments and in two out of three Bravo-treatments (Table 6). In Dotnuva, in 2008 a trend towards increasing of TGW was noted. In 2009, the increase was significant in the plots of all fungicide treatments, and in 2010 it was significantly higher in two out of three Signum-treatments.

Table 6. The effect of seed treatment and fungicide application on pea yield and 1000 grain weight (TGW) in Dotnuva and Perloja in 2008-2010

\begin{tabular}{|c|c|c|c|c|c|c|}
\hline \multirow{3}{*}{ Treatment } & \multicolumn{3}{|c|}{ Grain yield $t$ ha $^{-1}$} & \multicolumn{3}{|c|}{ TGW g } \\
\hline & 2008 & 2009 & 2010 & 2008 & 2009 & 2010 \\
\hline & \multicolumn{6}{|c|}{ Dotnuva } \\
\hline 1. Untreated / unsprayed & 2.52 & 2.07 & 2.63 & 232.8 & 232.8 & 224.0 \\
\hline 2. Untreated / Signum & 2.15 & 2.17 & 2.77 & 238.6 & $260.3 * *$ & $230.0 *$ \\
\hline 3. Untreated / Bravo & 2.31 & $2.29 *$ & $3.04 *$ & 235.1 & $257.4 * *$ & 226.4 \\
\hline 4. Kinto / unsprayed & 2.42 & 2.16 & 2.41 & 239.2 & $259.5 * *$ & 225.9 \\
\hline 5. Raxil extra / unsprayed & 2.52 & 2.05 & 2.40 & 239.1 & $256.8 * *$ & 229.8 \\
\hline 6. Kinto / Signum & 2.45 & $2.35 * *$ & 2.51 & 238.6 & $264.7 * *$ & 225.7 \\
\hline 7. Raxil extra / Signum & 2.38 & 2.22 & 2.27 & 235.2 & $260.4 * *$ & $228.2 * *$ \\
\hline 8. Kinto / Bravo & 2.26 & $2.38 * *$ & 2.76 & 235.5 & $262.3 * *$ & 230.6 \\
\hline \multirow[t]{2}{*}{ 9. Raxil extra / Bravo } & 2.45 & 2.18 & 2.38 & 234.8 & $260.3 * *$ & 229.6 \\
\hline & \multicolumn{6}{|c|}{ Perloja } \\
\hline 1. Untreated / unsprayed & 2.25 & 1.68 & 1.80 & 206.2 & 211.0 & 168.3 \\
\hline 2. Untreated / Signum & 2.55 & 1.73 & $2.21 * *$ & $213.0^{*}$ & 221.0 & $191.0 * *$ \\
\hline 3. Untreated / Bravo & 2.73 & 1.57 & 1.43 & 202.6 & 211.0 & $184.2 * *$ \\
\hline 4. Kinto / unsprayed & 2.32 & 1.51 & 1.74 & 206.6 & 206.8 & 162.9 \\
\hline 5. Raxil extra / unsprayed & 2.42 & 1.55 & $2.16^{*}$ & 207.4 & 207.4 & 165.2 \\
\hline 6. Kinto / Signum & 2.46 & 1.94 & 1.86 & 203.7 & $224.4 *$ & $199.6 * *$ \\
\hline 7. Raxil extra / Signum & 2.47 & 1.73 & 1.64 & $220.0 * *$ & $228.0 * *$ & $196.6^{* *}$ \\
\hline 8. Kinto / Bravo & 2.84 & 1.45 & 1.52 & 209.2 & 213.0 & $188.7 * *$ \\
\hline 9. Raxil extra / Bravo & $3.04 *$ & 1.66 & $2.40 * *$ & 190.0 & 218.3 & 181.9 \\
\hline
\end{tabular}

*,** $-F$-test significant at $P>0.05$ and $P>0.01$, respectively

When comparing the two years' data on pod and grain number and weight per plant (2008 and 2010), a trend was noticed, suggesting that in the seed-treated plots applied with fungicides the values of these indicators in most cases were higher than in the untreated/unsprayed, and in 2010 in Dotnuva, in two out of three Raxil extra - seed treated and fungicide applied treatment plots pod number per plant was significantly higher than that in the untreated/unsprayed. In the plots sown with only Raxil extra-treated seed there was also noted a trend for increasing of pod number. Also, in 2010, in Dotnuva, in the plots of all treatments of Raxil extra-treated seed, applied with fungicides at flowering and in the plots not applied with fungicides, as well as in Kinto/Bravo plots there was established a significantly higher grain number and weight per plant.

$P e a$ yield and its components in relation to area under disease progress curve (AUDPC) of ascochyta blight. During the whole experimental period (20082010), the significant negative correlation between TGW and AUDPC of ascochyta blight $(r=-45, P \leq 0.05)$ was found in 2009 in Perloja. Negative moderate correlation between pod and grain number per plant, grain weight per plant and AUDPC of ascochyta blight was established only in 2008 in Perloja, $r=-0.52,-0.53$ and -0.57 $(P \leq 0.01)$, respectively.

The data of research done in Australia by Bretag et al. (1995) show that yield losses to ascochyta blight are highly dependent on the variety, local conditions, time of infection spread in crops. In commercial fields, losses to ascochyta blight ranged from $3.1 \%$ to $26.4 \%$ and were higher than $15 \%$ in three quarters of the crops assessed. Xue (2000) indicated that treatment of seed infected with ascochyta blight causal agents improved germination under field conditions; however, the seed treatment did not give any grain yield increase. Conversely, the study done by Gorfu and Sangchote (2003) evidenced that seed treatment with Carbendazim resulted in a $13.2 \%$ pea grain yield increase, and Iprodione gave a yield increase of $12.5 \%$, compared with the untreated control. Xue et al. (2003) have reported that the spray-application of the crops of 10 pea varieties with Chlorothalonil provided a significant reduction in ascochyta blight pressure, an increase in grain yield and TGW in all the three experimental years; however, the variety $\times$ fungicide interaction was not significant in all years. The yield increase resulting from the fungicide application amounted to on average $6.4 \%$, and TGW increase was $0.9-5.1 \%$. Moreover, the pea seed treated with Chlorothalonil was $19.2 \%$ less infected with the propagules of $M$. pinodes. Tivoli et al. (1996) found that severe ascochyta blight infection can reduce seed number per plant, depending on the year's infection pressure, by $18 \%$ and $25 \%$ and seed size by $13.5 \%$ and $16.7 \%$, and give a seed yield reduction as high as $40 \%$, compared with healthy plants. In our study, we did not obtain such a difference, since even in fungicide-spray applied plots the plants were affected by ascochyta blight, although the disease severity was significantly lower. 


\section{Conclusions}

1. Ascochyta blight severity was significantly reduced by pea seed treatment with Raxil extra (a.i. tebuconazole + thiram $\left.15+500 \mathrm{~g} \mathrm{l}^{-1}\right) 2.0 \mathrm{t}^{-1}$ and Kinto (a.i. triticonazole + prochloraz $20+60 \mathrm{~g} \mathrm{l}^{-1}$ ) $1.51 \mathrm{t} \mathrm{t}^{-1}$ and/or at fungicide application at flowering stage with Signum (a.i. boscalid + piraclostrobin $267+67 \mathrm{~g} \mathrm{~kg}^{-1}$ ) $1.0 \mathrm{~kg} \mathrm{ha}^{-1}$ and Bravo (a.i. chlorothalonil $500 \mathrm{~g} \mathrm{l}^{-1}$ ) $3.01 \mathrm{ha}^{-1}$. The area under disease progress curve (AUDPC) values of ascochyta blight in the fungicide-applied plots in most cases were significantly lower in Dotnuva than Perloja experimental sites.

2. In Perloja, the fungi of Ascochyta complex on grain were detected in all experimental years, while in Dotnuva only in 2010. The grains of pea crops sprayapplied with the fungicides Signum and Bravo in two years out of three were less infected with the pathogens of Ascochyta complex, compared with those from the unsprayed plots. The frequency of detection of the pathogens of Ascochyta complex on pea pods and grain depended on the level of ascochyta blight severity. With rising infection level, the frequency of detection of pathogens increased both on pods and grain.

3. Pea grain yield increments resulting from the use of seed treatment and fungicide application were inconsistent in both experimental sites. It was noted that the values of productivity indicators, 1000 grain weight (TGW) and pod number per plant were higher for the Raxil extra seed-treated plots spray-applied with the fungicides Signum and Bravo; in separate years these values significantly differed from the untreated/unsprayed. In Perloja, in 2008, a significant negative correlation $(P$ $\leq 0.01$ ) was established between the AUDPC values of ascochyta blight and pod and grain number per plant and grain weight per plant, and TGW $(P \leq 0.05)$. Low correlation coefficients were obtained in Dotnuva because the ascochyta blight infection level was very low there.

\section{Acknowledgements}

The paper presents research findings, obtained through the long-term research programme "Harmful organisms in agro and forest ecosystems" implemented by Lithuanian Research Centre for Agriculture and Forestry.

Received 28122012 Accepted 16052013

\section{References}

Abbott W. S. 1925. A method of computing the effectiveness of an insecticide. Journal of Economic Entomology, 18: $265-267$

Bretag T. W., Price T. V. Keane P. J. 1995. Importance of seed-borne inoculum in the etiology of the ascochyta blight complex of field peas (Pisum sativum L.) grown in Victoria. Australian Journal of Experimental Agriculture, 35 (4): 525-530 http://dx.doi.org/10.1071/EA9950525

Bretag T. W., MacLeod W. J., Kimber R. B. E., Moore K. J., Kinghts E. J. C., Davidson J. A. 2008. Management of ascochyta blight in chickpeas in Australia. Australasian Plant Pathology, 37: 486-497 http://dx.doi.org/10.1071/AP08046

Buivydaite V. V., Vaičys M., Juodis J., Motuzas A. 2001. Classification of Lithuanian soils. Science and arts of Lithuania, book 34 (in Lithuanian)
Campbell C. L., Madden L. V. 1990. Temporal analysis of epidemics. I. Description and comparison of diseases progress curves. Campbell C. L., Madden L. V. (eds). Introduction to Plant Disease Epidemiology, p. 161-202

Chang K. F., Ahmed H. U., Hwang S. F., Gossen B. D., Strellkov S. E., Blade S. F., Turnbull G. D. 2007. Sensitivity of field populations of Ascochyta rabiei to chlorothalonil, mancozeb and pyraclostrobin fungicides and effect of strobilurin fungicides on the progress of ascochyta blight of chickpea. Canadian Journal of Plant Science, 87: 937-944 http://dx.doi.org/10.4141/CJPS07019

Clulow S. A., Lewis B. G., Matthews P. 1992. Expression of resistance to Mycosphaerella pinodes in Pisum sativum. Plant Pathology, 41: 362-369 http://dx.doi.org/10.1111/j.1365-3059.1992.tb02359.x

Davidson J. A., Kimber R. B. E. 2007. Integrated disease management of ascochyta blight in pulse crops. European Journal of Plant Pathology, 119: 99-110 http://dx.doi.org/10.1007/s10658-007-9132-x

Fougereux J. A., Meriaux B., Olivier V., Serandat I., Leclerc S., Avrillon M., Cassignol F., Dagorn C. 2006. A 20 years overview of pea seed contamination by Ascochyta sp. in France. Poster abstract (C11). Ascochyta workshop on grain legumes in Le Tronchet. Brittany, France, p. 7

Garry G., Jeuffroy M. H., Ney B., Tivoli B. 1998. Effects of ascochyta blight (Mycosphaerella pinodes) on the photosynthesizing leaf area and the photosynthetic efficiency of the green leaf area of dried-pea. Plant Pathology, 47: 473-479 http://dx.doi.org/10.1046/j.1365-3059.1998.00259.x

Gaurilčikienė I., Cesnulevičienè R., Janušauskaitė D. 2012. Management of seed borne root and foot rot diseases of pea (Pisum sativum L.) with fungicide seed treatment. Zemdirbyste-Agriculture, 99 (1): 77-84

González H. H. L., Resnik S. L., Boca R. T., Marasas W. F. O. 1995. Mycoflora of Argentinean corn harvested in the main production area in 1990. Mycopathologia, 130: 29-36 http://dx.doi.org/10.1007/BF01104346

Gorfu D., Sangchote S. 2003. Effects of seed treatment fungicides on Ascochyta pinodes of field pea under controlled and field conditions. Kasetsart Journal (Natural Science), 37 (4): 429-444

Kraft J. M., Dunne B., Goulden D., Armstrong S. 1998. A search for resistance in peas to Mycosphaerella pinodes. Plant Disease, 82: 251-253

http://dx.doi.org/10.1094/PDIS.1998.82.2.251

Marcinkowska J. 2008. Fungi occurrence on seed of field pea. Acta Mycologica, 43 (1): 77-89 http://dx.doi.org/10.5586/am.2008.010

Moussart A., Tivoli B., Lemarchand E., Deneufbourg F., Roi S., Sicard G. 1998. Role of seed infection by the ascochyta blight pathogen of dried pea (Mycosphaerella pinodes) in seeding emergence, early disease development and transmission of the disease to aerial plant parts. European Journal of Plant Pathology, 104: 93-102

http://dx.doi.org/10.1023/A:1008673914537

Onfroy C., Tivoli B., Corbiere R., Bouznad Z. 1999. Cultural, molecular and pathogenic variability of Mycosphaerella pinodes and Phoma medicaginis var. pinodella isolates from dried pea (Pisum sativum) in France. Plant Pathology, 48: $218-229$ http://dx.doi.org/10.1046/j.1365-3059.1999.00323.x

Panicker S., Ramraj B. 2010. Studies on the epidemiology and control of ascochyta blight of peas (Pisum sativum L.) caused by Ascochyta pinodes. Archives of Phytopathology and Plant Protection, 43 (1): 51-58 http://dx.doi.org/10.1080/03235400701652417

Persson L., Bødker L., Larsson-Wikstrom M. 1997. Prevalence and pathogenicity of foot and root rot in Southern Scandinavia. Plant Disease, 81: 171-174 http://dx.doi.org/10.1094/PDIS.1997.81.2.171 
Punithalingam E., Holliday P. 1972 (a). Ascochyta pisi. CMI Description of Pathogenic Fungi No. 334

Punithalingam E., Holliday P. 1972 (b). Mycosphaerella pinodes. CMI Description of Pathogenic Fungi No. 340

Punithalingam E., Gibson I. A. S. 1976. Phoma medicaginis var. pinodella. CMI Description of Pathogenic Fungi No. 518

Roger C., Tivoli B. 1996. Spatio-temporal development of pycnidia and perithecia and dissemination of spores of Mycosphaerella pinodes on pea (Pisum sativum). Plant Pathology, 45: 518-528 http://dx.doi.org/10.1046/j.1365-3059.1996.d01-139.x

Tarakanovas P., Raudonius S. 2003. Statistical analysis of agronomic research data using software ANOVA, STAT, SPLIT-PLOT from the package SELEKCIJA and IRRISTAT (in Lithuanian)

Tivoli B., Beasse C., Lemarchand E., Masson E. 1996. Effect of ascochyta blight (Mycosphaerella pinodes) on yield components of single pea (Pisum sativum) plants under field conditions. Annals of Applied Biology, 129: 207-216 http://dx.doi.org/10.1111/j.1744-7348.1996.tb05745.x

Tomm G. O., Kutcher H. R., Picinini E. C., Donida B. 2004. Control of foliar diseases of field pea in Southern Brazil. Proceedings of the $4^{\text {th }}$ International Crop Science Congress. Brisbane, Australia. <http://www.regional.org.au/au/ asa/2004/poster/2/4/2/419_tommgo.htm> [accessed 0311 2012]

Weber E., Bleiholder H. 2001. Phenological growth stages and BBCH-identification keys of pea (Pisum sativum). Growth sages of mono- and dicotyledonous plants. Meier U. (ed.) BBCH Monograph (2 ${ }^{\text {nd }}$ ed.), p. 138-140. <http://www.jki. bund.de/fileadmin/dam uploads/ veroeff/bbch/BBCHSkala_deutsch.pdf $>$ [accessed 1004 2013]

Xue A. G. 2000. Effect of seed-borne Mycosphaerella pinodes and seed treatments on emergence foot rot severity, and yield of field pea. Canadian Journal of Plant Pathology, 22 (3): 248-253 http://dx.doi.org/10.1080/07060660009500471

Xue A. G., Warkentin T. D., Greeniaus M. T., Zimmer R. C. 1996. Genotypic variability in seedborne infection of field pea by Mycosphaerella pinodes and its relation to foliar disease severity. Canadian Journal of Plant Pathology, 18: 370-374 http://dx.doi.org/10.1080/07060669609500590

Xue A. G., Warkentin T. D. 2001. Partial resistance to Mycosphaerella pinodes in field pea. Canadian Journal of Plant Science, 81 (3): 535-540 http://dx.doi.org/10.4141/P00-103

Xue A. G., Warkentin T. D., Kenaschuk E. O. 1997. Effects of timings of inoculation with Mycosphaerella pinodes on yield and seed infection of field pea. Canadian Journal of Plant Science, 77: 685-689 http://dx.doi.org/10.4141/P96-150

Xue A. G., Charest J., Davidson C. G., McAndrew D. W., Bing D. J., Warketin T. D. 2003. Response of field pea cultivars to chlorothalonil in the control of Mycospharella blight. Canadian Journal of Plant Science, 83: 313-318 http://dx.doi.org/10.4141/P02-046

ISSN 1392-3196 / e-ISSN 2335-8947

Zemdirbyste-Agriculture, vol. 101, No. 1 (2014), p. 101-108

DOI $10.13080 / \mathrm{z}-\mathrm{a} .2014 .101 .014$

\title{
Askochitozès (Ascochyta complex) kontrolẻ sẻjamųjų žirnių pasèlyje Lietuvos sąlygomis
}

\author{
R. Česnulevičiené1, I. Gaurilčikiené ${ }^{2}$, J. Ramanauskienè ${ }^{2}$ \\ ${ }^{1}$ Lietuvos agrariniu ir miškų mokslų centro Perlojos bandymu stotis \\ ${ }^{2}$ Lietuvos agrarinių ir miškų mokslų centro Žemdirbystès institutas
}

\section{Santrauka}

2008-2010 m. skirtingų dirvožemiu bei klimato sąlygomis: 1) Lietuvos vidurio žemumoje Dotnuvoje ir 2) Lietuvos pietryčių aukštumoje Perlojoje, atlikti žirnių askochitozės kontrolès ypatumų tyrimai, sẻklą apdorojus cheminiais beicais ir pasėlius nupurškus fungicidais. Ir Dotnuvoje, ir Perlojoje sèta tos pačios partijos veislès 'Pinochio' sėjamojo žirnio (Pisum sativum L.) komercinès paskirties sèkla. Sèklai beicuoti pasirinkti du beicai Raksil ekstra (v. m. tebukonazolas + tiramas $15+500 \mathrm{~g} \mathrm{l}^{-1}$ ) 2,0 $\mathrm{lt}^{-1}$ ir Kinto (v. m. tritikonazolas + prochlorazas $20+60 \mathrm{~g} \mathrm{l}^{-1}$ ) $1,5 \mathrm{l} \mathrm{t}^{-1}$. Pasėliams purkšti žydejjimo tarpsniu naudoti du fungicidai - Signum (v. m. boskalidas + piraklostrobinas $267+67 \mathrm{~g} \mathrm{~kg}^{-1}$ ) 1,0 $\mathrm{kg} \mathrm{ha}^{-1}$ ir Bravo (v. m. chlorotalonilas $500 \mathrm{~g} \mathrm{l}^{-1}$ ) 3,0 $1 \mathrm{ha}^{-1}$.

Beicuota sèkla apsètuose ir/ar žydèjimo tarpsniu fungicidais apdorotuose laukeliuose žirniu askochitozès intensyvumas buvo iš esmès mažesnis, nei neapdorotų. Dotnuvoje askochitozės AUDPC (plotas po ligos vystymosi kreive) reikšmès fungicidais apdorotuose laukeliuose daugeliu atvejų buvo iš esmès mažesnès nei Perlojoje. Askochitozès sukèleju (Ascochyta komplekso) aptikimo dažnis ant žirnių ankščių ir grūdu priklausè nuo ligos intensyvumo pasèlyje. Infekcijai smarkèjant, patogenų aptikimo dažnis didèjo ir ant ankščių, ir ant grūdų. Perlojoje žirniu grūdai Ascochyta komplekso grybais buvo infekuoti visais metais, o Dotnuvoje - tik 2010 m. Fungicidais Signum ir Bravo purkštų augalų grūdai dvejus metus iš trejų buvo mažiau užkrèsti Ascochyta komplekso patogenais nei nepurkšti. Žirnių derliaus padidejjimas nuo sėklos beicavimo ir fungicidų purškimo buvo nenuoseklus abiejose tyrimo vietose. Nustatyta, kad beicu Raksil ekstra apdorota sèkla sètų ir fungicidais Signum ir Bravo purkštų žirniu derlingumo rodikliai - 1000 grūdu masè bei ankščiu skaičius ant augalo - buvo didesni, o kai kuriais metais ir iš esmès skyrèsi nuo kontrolinio varianto. Perlojoje $2008 \mathrm{~m}$. nustatyta ankščiu bei grūdų skaičiaus ant augalo esminè neigiama koreliacija su askochitozès AUDPC reikšmėmis $(P \leq 0,01)$ ir vieno augalo grūdu masès - su AUDPC $(P \leq 0,05)$. Dotnuvoje dèl mažesnio askochitozès infekcijos lygio esminès koreliacijos tarp šių rodiklių nenustatyta.

Reikšminiai žodžiai: Ascochyta kompleksas, AUDPC, derlius, fungicidai, Pisum sativum, žirnių askochitozè. 